(RESEARCH ARTICLE)

\title{
Genotypic characterization of hepatitis B virus among human immunodeficiency virus patients at a tertiary health care facility in North Central Nigeria
}

\author{
Haruna Isa Mohammed *, Alaku Sarah and Pennap Grace Rinmecit \\ Department of Microbiology, Nasarawa State University, P.M.B. 1022, Keffi, Nigeria.
}

Publication history: Received on 29 April 2020; revised on 22 May 2020; accepted on 24 May 2020

Article DOI: https://doi.org/10.30574/wjarr.2020.6.2.0132

\begin{abstract}
Hepatitis B virus (HBV) remains a major global health problem, with approximately 257 million people chronically infected. HBV co-infection with human immunodeficiency (HIV) virus is a major public health problem especially in developing countries. In this study, the genotypes of HBV were determined among 400 consenting HIV patients accessing healthcare in Federal Medical Center, Keffi, Nigeria by Nested Multiplex PCR method. Blood samples were collected and screened for HBsAg using ACON kit (ACON Laboratories Inc, USA). HBV DNA from 18 positive samples were genotyped. Of these, $5.6 \%$ were of genotype B, $22.2 \%$ were of genotype $\mathrm{F}$ and $72.2 \%$ were not-typeable. This study reported the circulation of genotypes $\mathrm{B}$ and $\mathrm{F}$ in the study population with predominance of not-typable strains. To the best of our knowledge, this is the first report of genotype F in a Nigerian study.
\end{abstract}

Keywords: Hepatitis B; HIV; Genotype; PCR; Nigeria

\section{Introduction}

Hepatitis B virus (HBV) remains a major global health problem, with approximately 257 million people chronically infected [1]. HBV, HCV and HIV are blood borne viral infections that have been widely reported in Nigeria [2]. Viral hepatitis is now the seventh leading cause of death worldwide with a 63\% mortality increase to 1.45 million from 1990 to 2013 [3]. HBV accounts for most viral hepatitis associated deaths [3]. It is endemic in Africa and Western Pacific, with about $6 \%$ chronic infections in adults [1]. In Nigeria, HBV is reported to be the most common cause of liver disease [4]. The prevalence of HBV infection in the general population in Nigeria ranges from $9 \%$ to 39\% [5,6,7], and being above $8 \%$ considered hyperendemic [8]. Pennap et al. also reported HBsAg prevalence of $12.5 \%$ among HIV infected patients [6]. Co-infection with HIV and HBV has become an important factor of co-morbidity and mortality [9]. HBV is a prototype member of the Hepadnaviridea family and it is classified into 10 genotypes (A-J) with different geographical distributions, clinical features and responses to treatment [10]. There is a call by World Health Organization to eliminate HBV and HCV infections as a public Health problem by 2030 [11]. To achieve this, robust sequence data of HBV isolated from patients are necessary. However, there is paucity of HBV genotyping data in Nigeria. Similarly, the knowledge of the circulating genotypes is important for optimal treatment strategy especially in chronic patients. Thus, the aim of this study was to detect the HBV genotypes circulating in the study area from individuals accessing healthcare in Federal Medical Centre, Keffi, Nigeria.

\section{Materials and methods}

\subsection{Study area and population}

The study centre for this research was Federal Medical Center, located in Keffi Local Government Area of Nasarawa State, Nigeria.

\footnotetext{
${ }^{*}$ Corresponding author: Haruna Isa Mohammed
} 
Keffi is approximately $68 \mathrm{~km}$ from Abuja, the Federal Capital Territory and 128km from Lafia, the capital of Nasarawa State.

Keffi town is located geographically between latitude $803^{\prime} \mathrm{N}$ of the equator and longitude 7050 'E and situated on an altitude of $850 \mathrm{~m}$ above sea level [12]. The study was conducted on 400 consenting HIV positive individuals accessing Antiretroviral Therapy (ART) in Federal Medical Centre, Keffi Nigeria.

The socio-demographic information of the participants was obtained by the use of a designed questionnaire. The study involved both male and female adult patients accessing ART in Federal Medical Centre. Such patients are mainly from Keffi and other surrounding Local Government Areas. Those within Keffi metropolis were categorized as urban while those outside Keffi metropolis and other surrounding local government areas were categorized as rural.

\subsection{Sample size determination}

The sample size for this study was determined using the formula by Thrusfield [13]:

$$
N=\frac{(1.96)^{2} \times P \exp (1-p \exp )}{D^{2}}
$$

Where:

$\mathrm{N}=$ Number of samples

Pexp $=$ Expected prevalence of 12.3

$\mathrm{D}^{2}=$ Desired absoluted precursor of 5

$$
\begin{aligned}
& N=3.84 \times 0.12 \times 0.88 /(0.05)^{2} \\
& N=0.4048 / 0.0025 \\
& N=161.92
\end{aligned}
$$

This was however rounded up to 400 samples.

\subsection{Sample collection}

A total of 400 blood samples were collected from patients in the ART clinic of Federal Medical Center, Keffi from May through August, 2018. About $2 \mathrm{ml}$ of blood sample was collected from each consenting participant using a sterile vacuutainer. The arm of the individual was tied with a tourniquet and the position of a vein was disinfected using cotton wool soaked in methylated spirit. Using a sterile labeled vacuutainer for each participant, a blood sample was collected from each of them as described by Cheesbrough [14].

\subsection{Laboratory analysis}

\subsubsection{Screening for $\mathrm{HBs} A g$}

Screening for HBsAg from the HIV infected patients' blood samples was done using the Acon rapid test kit (ACON USA) in accordance with the manufacturer's instructions.

\subsubsection{Hepatitis B virus DNA extraction}

The viral DNA was extracted using ZR Viral DNA Kit (Zymo Research Corp) according to the manufacturer's instructions.

\subsubsection{Buffer preparation}

Before starting, beta mercaptoethanol $\left(\mathrm{C}_{2} \mathrm{H}_{6} \mathrm{OS}\right)$ was added to the Viral DNA buffer to a final dilution of $0.5 \% \mathrm{v} / \mathrm{v}$. About $2 \mathrm{ml}$ of $100 \%$ ethanol was also added to the $6 \mathrm{ml}$ Viral Wash Buffer. 


\subsubsection{Procedure}

Four hundred microliter of Genomic Lysis Buffer was added to $100 \mu$ l of the sample in a ratio 4:1. It was mixed by vortexing for $6 \mathrm{sec}$, and left to stand for $15 \mathrm{~min}$ at room temperature. The mixture was transferred to a Zymo-Spin IIC Column in a collection tube and centrifuged at 10,000x g for $1 \mathrm{~min}$. The flow through was discarded with the collection tube. The Zymo-Spin IIC Column was transferred to a new tube, and was then centrifuged at 10,000 x g for another1min. To the column, $200 \mu \mathrm{l}$ DNA Pre-Wash Buffer was added and centrifuged at 10,000 x g for 1 min. Five hundred microlitre of g-DNA Wash Buffer was added to the spin column, centrifuged at 10,000 x g for 1 min and transferred to a clean micro centrifuge tube. Fifty microliter DNA Elution Buffer was added to the spin column incubated for 5 min at room temperature and then centrifuged at top speed for $30 \mathrm{sec}$ to elude the DNA.

\subsubsection{Oligonucleotide primers}

The primer pairs used for this research work were adopted from the work of Hideo et al [15].

\subsubsection{Polymerase chain reaction (PCR)}

For PCR amplification, $15 \mu \mathrm{l}$ of Master Mix containing tags, primers, nucleotide sequence, magnesium chloride, buffer, dnTP and template was added to 18 labeled PCR tubes because 18 of the HBsAg seropositive samples were picked at random for the first amplification (Nested PCR method), $0.48 \mu$ l each of the forward and reverse primers (P1) were added to the labeled PCR tubes and $9.2 \mu \mathrm{l}$ of nuclease free water was also added.

A quantity of $1 \mu \mathrm{l}$ of the extracted DNA added to the solution and centrifuged at $5000 \mathrm{rpm}$ for 30 sec to bring down any hanging fluid by the side or cover of the PCR tubes. Finally, the PCR tubes containing the master mix, reverse and forward primers (P1), nuclease free water and extracted DNA was laid over the reaction mixture. The reaction was programmed to first incubate the mixture for $10 \mathrm{~min}$ at $95^{\circ} \mathrm{C}$, followed by 40 cycles consisting of $94^{\circ} \mathrm{C}$ for $20 \mathrm{sec}, 55^{\circ} \mathrm{C}$ for $20 \mathrm{sec}$, and $72^{\circ} \mathrm{C}$ for $1 \mathrm{~min}$. Second round PCR (Nested-Multiplex PCR method) were performed for all the samples, with the common universal sense primer and mix A for types A through $C$ and the common universal antisense primer and mix B for types D through F. A $1 \mathrm{ml}$ aliquot of the first PCR product was added to tubes containing primers specific for types A through $\mathrm{C}$ and primers specific for types $\mathrm{E}$ through $\mathrm{F}$. These were amplified for 40 cycles with the following parameters: preheated at $95^{\circ} \mathrm{C}$ for $10 \mathrm{~min}, 20$ cycles of amplification at $94^{\circ} \mathrm{C}$ for $20 \mathrm{sec}, 58^{\circ} \mathrm{C}$ for $20 \mathrm{sec}$, and $72^{\circ} \mathrm{C}$ for $30 \mathrm{sec}$, and 20 cycles at $94^{\circ} \mathrm{C}$ for $20 \mathrm{sec}, 60^{\circ} \mathrm{C}$ for $20 \mathrm{sec}$, and $72^{\circ} \mathrm{C}$ for $30 \mathrm{sec}$.

\subsubsection{Agarose gel electrophoresis}

Agarose gel was prepared by mixing $1 \mathrm{~g}$ of Agarose powder with $100 \mathrm{ml}$ 1X Tris Borate Ethylenediamine tetraacetic acid (EDTA) in a conical flask and dissolved by heating in a microwave oven for $10 \mathrm{~min}$. The preparation was allowed to cool to about 450C. The gel was poured into the tank with the gel casting trays and combs in place, $5 \mu \mathrm{l}$ of Ethidium Bromide solution was added into the conical flask and gently swirled. The combs were carefully removed from the tank after gelling.

The first well was loaded with $5 \mu \mathrm{l}$ of the XbP DNA Ladder and the second loaded with $10 \mu \mathrm{l}$ nuclease free water mixed with $5 \mu \mathrm{l}$ 6X loading dye. The remaining wells were loaded with $10 \mu \mathrm{l}$ PCR amplicons of the second amplification. The voltage for the electrophoresis was set at $120 \mathrm{~V}$ and allowed to run for $45 \mathrm{~min}$. The gel tray was removed and transferred to the computer room for observation and photographing of the results which were printed out.

\subsection{Ethical approval}

Ethical clearance and approval to conduct this study was sought and obtained from the Health Research Ethics Committee of Federal Medical Centre, Keffi, Nasarawa State on 6th February, 2018.

\subsection{Statistical analysis}

Chi Square analysis was used to test for significance using Smith Statistical Package (SSP) version 2.8. The statistical significance was determined at $5 \%$ probability $(\mathrm{P} \leq 0.05)$. 
Table 1: The distribution of HBV genotypes in relation to socio-demographic factors among HIV positive patients accessing healthcare in Federal Medical Centre, Keffi, Nigeria.

\begin{tabular}{|c|c|c|c|c|}
\hline Socio-demographic & No. Examined & Genotype B (\%) & Genotype F (\%) & Not-typeable (\%) \\
\hline \multicolumn{5}{|l|}{ Gender } \\
\hline Male & 7 & $1(14.3)$ & $0(0.0)$ & $6(85.7)$ \\
\hline Female & 11 & $0(0.0)$ & $4(36.3)$ & $7(63.6)$ \\
\hline Total & 18 & $1(5.6)$ & $4(22.2)$ & $13(72.2)$ \\
\hline \multicolumn{5}{|l|}{ Age (Years) } \\
\hline $18-27$ & 1 & $0(0.0)$ & $1(100.0)$ & $0(0.0)$ \\
\hline $28-37$ & 6 & $0(0.0)$ & $0(0.0)$ & $6(100.0)$ \\
\hline $38-47$ & 8 & $1(12.5)$ & $2(25.0)$ & $5(62.5)$ \\
\hline $48-57$ & 2 & $0(0.0)$ & $1(50.0)$ & $1(50.0)$ \\
\hline$\geq 58$ & 1 & $0(0.0)$ & $0(0.0)$ & $1(100.0)$ \\
\hline Total & 18 & $1(5.6)$ & $4(22.2)$ & $13(72.2)$ \\
\hline \multicolumn{5}{|l|}{ Marital Status } \\
\hline Single & 10 & $0(0.0)$ & $3(30.0)$ & $7(70.0)$ \\
\hline Married & 6 & $0(0.0)$ & $0(0.0)$ & $6(100.0)$ \\
\hline Divorced & 2 & $1(50.0)$ & $1(50.0)$ & $0(0.0)$ \\
\hline Total & 18 & $1(5.6)$ & $4(22.2)$ & $13(72.2)$ \\
\hline \multicolumn{5}{|l|}{ Educational Status } \\
\hline Primary & 2 & $0(0.0)$ & $2(100.0)$ & $0(0.0)$ \\
\hline Secondary & 10 & $0(0.0)$ & $2(20.0)$ & $8(80,0)$ \\
\hline Tertiary & 6 & $1(116.7)$ & $0(0.0)$ & $5(83.3)$ \\
\hline Total & 18 & $1(5.6)$ & $4(22.2)$ & $13(72.2)$ \\
\hline \multicolumn{5}{|l|}{ Occupation } \\
\hline Student & 10 & $0(0.0)$ & $2(20.0)$ & $8(80.0)$ \\
\hline Farmers & 2 & $0(0.0)$ & $1(50.0)$ & $1(50.0)$ \\
\hline Unemployed & 4 & $0(0.0)$ & $1(25.0)$ & $3(75.0)$ \\
\hline Artisan & 1 & $0(0.0)$ & $0(0.0)$ & $1(100.0)$ \\
\hline Civil Servant & 1 & $1(100.0)$ & $0(0.0)$ & $0(0.0)$ \\
\hline Total & 18 & 1(5.6) & $4(22.2)$ & $13(72.2)$ \\
\hline \multicolumn{5}{|l|}{ Locality } \\
\hline Urban & 5 & $0(0.0)$ & $0(0.0)$ & $5(100.0)$ \\
\hline Rural & 13 & $1(7.7)$ & $4(30.8)$ & $8(61.5)$ \\
\hline Total & 18 & $1(5.6)$ & $4(22.2)$ & $13(72.2)$ \\
\hline
\end{tabular}




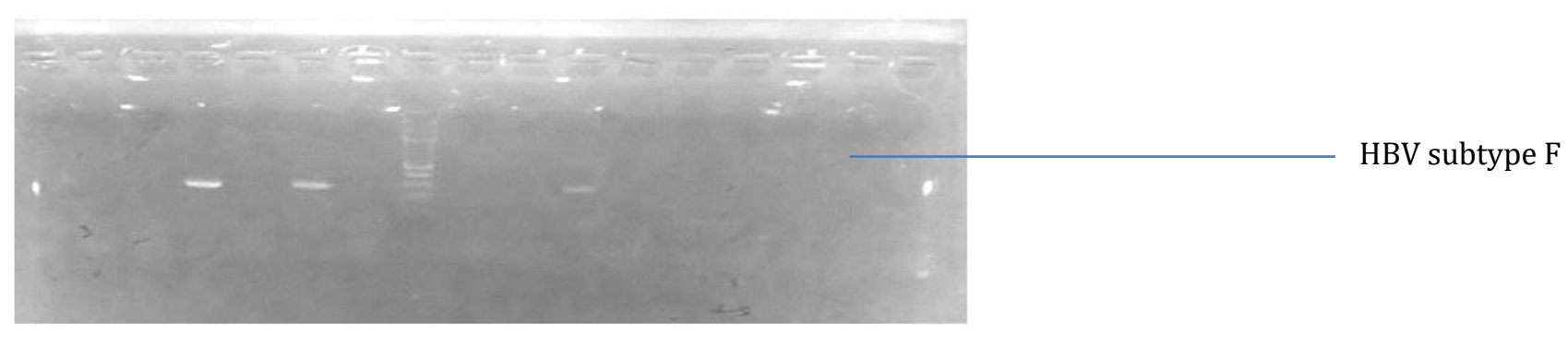

HBV subtype B

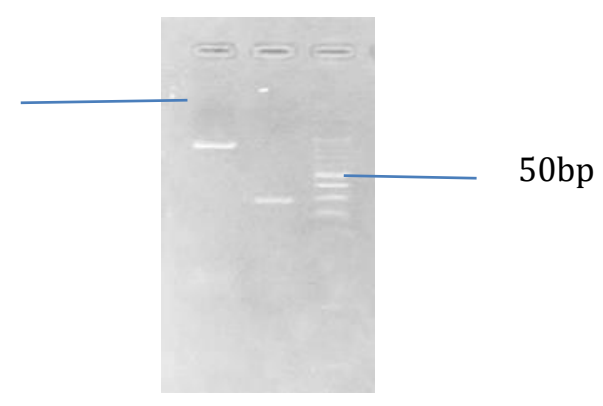

Figure 1 Agarose gel electrophoresis showing the different HBV genotypes. Lane 4, 6, 10 and 18 showed the genotype F at $97 \mathrm{bp}$ while lane 17 showed the subtype B at 281bp. Lane L represents the molecular ladder.

\section{Results and discussion}

A total of 400 HIV seropositive patients participated in the study. Eighteen HBsAg positive samples were genotyped of which genotype B, F and genotypes that were not-typeable were observed (Figure 1). There were 7 males and 11 females. Of the 11 from females, four were of genotype $F$ between the ages of 20-29 years and 40-49 years, three were married and one was divorced, two had a primary education and two, a tertiary education, two of them were students, one a farmer and one was unemployed. All of them came from the rural setting (Table 1). The B genotype was from a male, between the ages of 40-49 years, he was divorced, had a tertiary education, and an artisan from the rural setting. Of the not-typeable, 6 were males and seven were females. Their ages ranged from 29- $\geq 50$ years. Singles were 7 and 6 were married. Those with a secondary education were 8 and 5 had a tertiary education. Students were 8 , one was a farmer, one unemployed and one a civil servant. All of them were from the rural setting.

Hepatitis B virus infection among seropositive Human Immunodeficiency virus patients is a growing public health problem [6]. Four hundred HIV positive patients accessing ART in Federal Medical Centre, Keffi were recruited for this study.

Of the 18 HBV DNA genotyped, $22.2 \%$ were of genotype F, 5.6\% of B while $72.2 \%$ were not-typeable (Figure 1 ). It is possible that HBV positive samples whose genotypes were not-typeable were from those whose primers were not available, errors in DNA extraction or PCR procedures. Earlier studies in Nigeria have reported the circulation of genotype E in Benin among HIV population [16]. Zampino et al. and Pennap et al. reported the HBV genotype E as the most frequent genotype in Nigeria [17, 18]. Genotype A has also been reported [19]. Genotype E was also reported among patients attending Akure hospitals in Nigeria [20]. Genotypes A and E were also found to be in Zaria with a predominance of E [21]. Another study done on occult hepatitis B virus among blood donors in Nigeria showed genotype $\mathrm{E}$ [22]. There is no published report of genotype $\mathrm{F}$ so far, it is possible that this genotype was acquired by those who travel to a country reported to have genotype $\mathrm{F}$.

\section{Conclusion}

There was a HBV prevalence of 7.5\% among HIV patients accessing healthcare in Federal Medical Centre, Keffi. Genotypes B (5.6\%) and F (22.2\%) were found to be in circulation in the study population, there was predominance $(72.2 \%)$ of not-typeable genotypes. This study is reporting the novel appearance of genotype $\mathrm{F}$ in Nigeria. There is therefore a need to screen for HBV among HIV positive patients and also genotypes to increase treatment efficiency. 


\section{Compliance with ethical standards}

\section{Acknowledgments}

The study team would like to thank the study participants who voluntarily participated in the study. However, this research did not receive any form of grant from governmental or non-governmental organizations.

\section{Disclosure of conflict of interest}

The authors declare that they have no known competing financial interests or personal relationships that could have appeared to influence the work reported in this paper.

\section{Statement of ethical approval}

Ethical clearance and approval to conduct this study was sought and obtained from the Health Research Ethics Committee of Federal Medical Centre, Keffi, Nasarawa State on 6th February, 2018.

\section{Statement of informed consent}

All individuals included in this study completed and signed an informed consent form. Individual anonymity was treated with confidentiality and for the purpose of this study.

\section{References}

[1] World Health Organization. (2017). Global hepatitis programme: Global hepatitis report.

[2] Oti BV, Pennap GR and Ngari HR. (2017). HBsAg and anti-HCV prevalence among pregnant women accessing antenatal care in a tertiary healthcare facility in Central Nigeria, Hepatology and Pancreas Science, 2, 110-113.

[3] Stanaway JD, Flaxman AD, Naghavi M, Fitzmaurice C, Vos T, Abubakar I, AbuRaddad LJ, Assadi R, Bhala N and Cowie B. (2016). The global burden of viral hepatitis from 1990 to 2013: Findings fromthe global burden of disease Study 2013. Lancet, 388, 1081-1088.

[4] Musa BM, Busell S, Borodo MM, Samaila AA and Femi OL. (2015). Prevalence of hepatitis B virus infection in Nigeria: A systematic review and meta-analysis. Nigerian Journal of Clinical Practice, 18, 163-172.

[5] Tula MY and Iyoha 0. (2015). A cross-sectional study on the seroprevalence of HBsAg among apparently healthy students of a tertiary institution in North-eastern Nigeria. International Journal Tropical Disease and Health, 7(3), 102-108.

[6] Pennap GR, Oti BV, Alaribe AG, Ajegena SA and Galleh PR. (2017). Seroprevalence of hepatitis B and C among human immunodeficiency virus infected patients in Federal Medical Center Keffi. Journal of Advances in Microbiology, 3(4), 1-6.

[7] Mohammed HI, Pennap GR, Oti BV and Adoga MP. (2019). Markers of hepatitis B virus infection in a subset of young people in central Nigeria. Scientific Africa, 5, e00121

[8] World Health Organization. (2010). Prevalence of hepatitis B virus infection in the World by Country.

[9] Djuidje MM, Cyriaque AA, Marlene TIG and Paul FM. (2017). Human immunodeficiency virus and hepatitis B virus co-infection in people living with HIV/AID identified in Yaoundé central hospital, Cameroon: Seroprevalence and impact on disease progression. Journal of AIDs and HIV Research, 9(6), 123-128.

[10] Croagh CM, Desmond PV and Bell SJ. (2015). Genotypes and viral variants in chronic hepatits B: A review of epidemiology and clinical relevance. World Journal of Hepatology, 7, 289-303.

[11] World Health Organization. (2018). Draft Global Health Sector Strategies.

[12] Akwa VL, Binbol NL, Samaila KL and Marcus ND. (2007). Geographical Perspective of Nasarawa State, Onaive Printing and Publishing Company Ltd, Keffi, 50.

[13] Thrusfield M. (1997). Veterinary epidemiology, Blackwell publishing, Edinburgh, 55.

[14] Cheesbrough M. (2006). District Laboratory practice in tropical countries. 2nd ed. Cambridge University press, USA, 297. 
[15] Hideo N, Hayashi S and Abe K. (2001). Rapid and specific genotyping system for hepatitis B virus corresponding to six major genotypes by using type specific primer. Journal of Clinical Microbiology, 39(1), 362-364.

[16] Oladeinde BH, Ejejindu IM, Omoregie R, Odia I, Aguh OB and Okwu UM. (2018). New strains of hepatits B virus genotype E circulating in Nigeria. International Journal of Health Science, 12, 6-12.

[17] Zampino R, Boemio A, Sagnelli C, Alessio L, Adinolfi L and Coppola N. (2015). Hepatitis burden in developing countries. World Journal of Gastroenterology, 21(42), 11941-11953.

[18] Pennap GR, Mohammed HI, Oti BV and Adoga MP. (2019). Genotype distribution of hepatitis B virus in a subset of infected young people in Central Nigeria. Scientific Africa, 5, e00122.

[19] Akintule OA, Olushola BA, Odaibo GN and Olaleye OD. (2018). Occult HBV infection in Nigeria. Archives of Basic and Applied Medicine, 6, 1-9.

[20] Onifade AK and Otun KO. (2017). Seroprevalence and genotyping of hepatitis B virus infection among patients attending selected hospitals in Akure, Nigeria. Futa Journal of Research in Science, 13, 2-11.

[21] Ahmad AE, Bakari AG, Musa BOP, Mustapha SK, Jamoh BY, Abdullahi IN, Tahir MI, Olatunji AO, Maishanu SH, Suleiman AB, Tolulope A, Hawkins C, Sagay AS, Zoakah A and Olayinka AT. (2019). Pattern of prevalent hepatitis $B$ virus genotypes in Zaria, Nigeria, Nigerian Postgraduate Medical Journal, 26 (2), 80-86.

[22] Oluyinka 00, Tong HV, Bui-Tien S, Fagbami AH, Adekanle O, Ojuronge O, Bock CT, Kresner PG and Velevan TP. (2015). Occult HBV infestion in Nigerian blood donors and hepatitis B virus transmisission risks. Plos one, 10(7), e0131912.

\section{How to cite this article}

Mohammed HI, Alaku S and Pennap GR. (2020). Genotypic characterization of hepatitis B virus among human immunodeficiency virus patients at a tertiary health care facility in North Central Nigeria. World Journal of Advanced Research and Reviews, 6(2), 187-192. 